\title{
Interactive comment on "Migrating and Non-Migrating Tides Observed in the Stratosphere from FORMOSAT-3/COSMIC Temperature Retrievals" by Uma Das et al.
}

\section{Uma Das et al.}

umakota@gmail.com

Received and published: 25 December 2019

Authors thank the Reviewer for her/his positive comments and suggestions. Please note that point by point replies are given below in blue in the supplement file.

Please also note the supplement to this comment:

https://www.ann-geophys-discuss.net/angeo-2019-140/angeo-2019-140-AC2-

supplement.pdf

Interactive comment on Ann. Geophys. Discuss., https://doi.org/10.5194/angeo-2019-140, 2019. 